\title{
Meningkatkan Hasil Pembelajaran Bahasa Indonesia Materi Teks Cerita Novel Melalui Penerapan Model Pembelajaran Discovery Learning
}

\author{
Prihadi Agus Wibowo ${ }^{1}$ \\ 'SMK Negeri 2 Rangkasbitung, \\ Lebak, Indonesia \\ email: prihadiaguswibowo@gmail.com
}

\begin{abstract}
Abstrak
Adapun tujuan penelitian ini adalah untuk mengetahui peningkatan hasil belajar bahasa Indonesia pada materi cerita novel, bagi siswa kelas XII Akuntansi melalui penerapan model pembelajaran Discovery Learning. Penelitian ini dilakukan di SMK kelas XII Akuntansi Semester Ganjil tahun pelajaran 2018/2019 dengan jumlah siswa dengan jumlah 32 orang. Penelitian ini dilakukan dalam dua siklus, tiap siklus dalam penelitian meliputi empat langkah yaitu (1) perencanaan (planning), (2) pelaksanaan (acting), (3) observasi (observing), (4) refleksi (reflecting). Indikator keberhasilan penelitian ini adalah selama proses pembelajaran dan dilakukannya refleksi ternyata adanya peningkatan pencapaian hasil belajar bahasa Indonesia siswa. Hasil Penelitian yang diperoleh dalam penelitian ini adalah: 1) hasil pada siklus I nilai rata - rata 82, 2) ketuntasan Belajar pada siklus I adalah $88 \%$, 3) hasil pada siklus II nilai rata-rata 85,4 , dan 4) Ketuntasan Belajar pada siklus II adalah $100 \%$. Berdasarkan data penelitian dan pembahasan dapat diambil kesimpulan bahwa dengan menerapkan model pembelajaran Discovery Learning pada mata pelajaran bahasa indonesia dapat meningkatkan hasil belajar siswa kelas XII Akuntansi tahun pelajaran 2018/2019.
\end{abstract}

Kata Kunci: Hasil Belajar, Bahasa Indonesia, Teks Cerita Novel, Model Discovery Learning.

\begin{abstract}
The purpose of this study was to see the improvement of Indonesian language learning outcomes in novel story material, for students of class XII Accounting through the Discovery Learning learning model. This research was conducted at SMK, class XII of Accounting for the Odd Semester in the 2018/2019 academic year with 32 students. This research was conducted in two cycles, each cycle in the study included four steps, namely (1) planning, (2) implementation, (3) observation, (4) reflection. The indicators of this research are during the learning process and it seems that the reflection turns out to be an increase in student learning outcomes. The results obtained in this study were: 1) the results in the first cycle an average of 82,2 ) the completeness of learning in the first cycle was $88 \%, 3$ ) the results in the second cycle an average value of 85.4 , and 4) learning completeness in cycle II is $100 \%$. Based on research data and discussion, it can be concluded that by applying the Discovery Learning model to Indonesian subjects, it can improve the learning outcomes of students in class XII Accounting at in the 2018/2019 academic year.
\end{abstract}

Keywords: Learning Outcomes, Indonesian Language, Novel Story Text, Discovery Learning Model.

\section{Pendahuluan}

Mata pelajaran Bahasa Indonesia adalah salah satu mata pelajaran yang wajib diikuti oleh siswa SMK Negeri 2 Rangkasbitung. Dalam penglompokan mata pelajaran SMK sesuai dengan struktur kurikulum SMK yang merupakan lampiran dari SK Dirjen Dikdasmen, No.130/D/KEP/KR/2017, bahwa mata pelajaran Bahasa Indonesia termasuk dalam kelompok

\footnotetext{
${ }^{*}$ Corresponding author.
}

Received 03 Februari 2020; Accepted 31 July 2020; Available online 1 September 2020 (c) 2020 MPI. All Rights Reserved 
muatan nasional. Oleh karenanya pembelajaran mata pelajaran Bahasa Indonesia sdiperuntukkan sebagai sarana mengembangkan kemampuan dan keterampilan menalar peserta didik. Pada dasarnya, pembelajaran Bahasa Indonesia memiliki tujuan untuk membimbing perkembangan bahasa peserta didik secara berkelanjutan melalui proses menyimak, memirsa, berbicara, membaca dan menulis. Pada akhirnya, tujuan pembelajaran Bahasa Indonesia ialah membimbing peserta didik untuk menggunakan bahasa sebagai media belajar, mengekspresikan ide dengan jelas dan lancar serta mampu berkomunikasi secara efektif (Ahmadi, 1990).

Bahasa memiliki peran sentral dalam perkembangan intelektual, sosial dan emosional. Bahasa Indonesia merupakan bahasa pengantar pendidikan di semua jenis dan jenjang pendidikan mulai dari pendidikan dasar, menengah hingga pendidikan tinggi (Maria, 2010). Bahasa Indonesia memegang peranan penting dalam upaya meningkatkan mutu pendidikan dimulai dari tingkat pendidikan dasar ( SD dan SMP) hingga tingakat Pendidikan Menengah (SMA dan SMK) penanaman kemampuan berbahasa Indonesia yang dimulai dari tingkat dasar siswa dibentuk untuk mempercepat penguasaan ilmu pengetahuan dan teknologi yang berkembang sangat pesat di era globalisasi ini (Aminudin, 1987).

Kemampuan berbahasa khususnya kemampuan dalam bahasa indonesia merupakan sarana berpikir untuk menumbuh kembangkan cara berpikir logis, sistematis dan kritis (Hadiono et al., 2016). Sedangkan pembelajaran bahasa Indonesia di SMK berdasarkan kompetensi Inti diorientasikan untuk kemampuan mengolah, menalar dan menyaji dalam ranah kongret dengan pengembangan dari yang dipelajarinya disekolah secara mandiri, bertindak secara efektif dan kreatif serta mampu menggunakan metode sesuai dengan kaidah keilmuan (Hidayat et al., 1990). Meningkatkan kemampuan siswa dalam berkomunikasi dengan menggunakan bahasa Indonesia yang baik dan benar, secara lisan maupun tertulis, serta menimbulkan penghargaan terhadap hasil cipta manusia Indonesia juga hal yang menjadi prioritas dalam pembelajaran bahasa indonesia di SMK. Berdasarkan hasil pengamatan peneliti terhadap pembelajaran bahasa Indonesia di kelas XII. Akuntansi pada Semester ganjil SMK Negeri 2 Rangkasbitung, hasil yang dicapai siswa belum mencapai kemampuan yang optimal dalam memahami struktur dan kaidah cerita pendek, sehingga nilai yang dicapai siswa belum mencapai nilai standar yang ditentukan sekolah yaitu 70 untuk mata pelajaran bahasa Indonesia.

Berdasarkan hasil prasiklus yang dilakukan pada tahap awal penelitian ini menunjukkan nilai rata-rata 77,4 dan ketercapaian hasil pembelajaran adalah $37 \%$. Dalam kondisi demikian peran guru adalah memegang peranan. Kemampuan guru dalam membuat siswa untuk mencapai hasil belajar mata pelajaran bahasa indonesia yang baik adalah merupakan kemampuan atau profesionalime guru (Husana et al., 1987).

Berkaitan dengan hal tersebut diatas maka dalam pelaksanaan Penelitian Tindakan Kelas ini Peneliti mengangkat mata pelajaran bahasa Indonesia yang menitik beratkan pada materi tentang ceritera Novel. Maka judul Penelitian Tindakan Kelas ini adalah "Meningkatkan Hasil Pembelajaran Bahasa Indonesia Materi Teks Cerita Novel Melalui Penerapan Model Pembelajaran Discovery Learning Siswa Kelas XII. Akuntansi Semester Ganjil SMK Negeri 2 Rangkasbitung Tahun Pelajaran 2018/2019.

Berdasarkan latar belakang yang telah disampaikan, maka Penelitian Tindakan Kelas ini bertujuan untuk meningkatkan hasil belajar mata pelajaran Bahasa Indonesia dengan materi Teks cerita Novel bagi siswa kelas XII Akuntansi Semester Ganjil SMK Negeri 2 Rangkasbitung melalui penerapan model pembelajaran Discovery Liarning.

\section{Metode Penelitian}

Penelitian Ini dilakukan di SMK Negeri 2 Rangkasbitung Tahun Pelajaran 2018/2019 dengan Subjek Penelitian sebanyak 32 orang siswa kelas XII Akuntansi Semester Ganjil. Waktu Penelitian mulai dari Perencanaan sampai dengan penulisan laporan hasil Penelitian ini dimulai dari Bulan Juli s.d Desember tahun 2018.

Subjek Penelitian ini adalah siswa kelas XII Akuntansi Semester Ganjil SMK Negeri 2 Rangkasbitung sebanyak 32 orang siswa. Sedangkan objek dari penelitian ini adalah hasil 
belajar siswa pada mata pelajaran Bahasa Indonesia melalui penerapan model pembelajaran Diuscovery Learning.

Pelaksananaan Penelitian Tindakan Kelas ini terdiri dari dua siklus, dimana setiap siklus terdiri dari komponen-komponen yaitu :

\section{Tahap Perencanaan (Planning)}

Pada tahap ini Peneliti menyusun Rencana Perencanaan Pembelajaran (RPP), materi pokok yang akan diajarkan kepada siswa bersama dengan Indikatornya. Pelaksanaan pada siklus I, II, direncanakan sesuai dengan yang tertuang dalam RPP. Selanjutnya dilakukan pemilihan masalah yang potensial diangkat dalam penelitian ini atau sesuai judul yang telah disetujui dalam proposal Penelitian Tindakan Kelas ini. Pelaksanaan Studi Pendahuluan, dengan melakukan perumusan masalah, memilih pendekatan yang akan diterapkan dalam penelitian ini, kemudian menentukan variabel dan menentukan sumber data, melalui tes prasiklus. Mempersiapkan alat dan bahan adalah hal penting dalam penelitian ini, dan penyusunan instrumen tes uji kompetensi serta lembar observasi.

Untuk memperjelas permasalah yang akan dibahas dalam laporan penelitiann ini, maka secara paralel Peneliti juga melakukan studi perpustakaan untuk mencari sumbersumber bacaan terkait dengan Penelitian Tindakan Kelas ini.

\section{Pelaksanaan tindakan (Acting)}

Kegiatan yang dilakukan pada tahap ini adalah melaksanakan pembelajaran sebagaimana scenario pembelajaran yang telah ditetapkan pada RPP.

\section{Pengamatan (Observasi)}

Pada tahap ini dilakukan proses observasi terhadap pelaksanaan tindakan dengan menggunakan lembar observasi yang telah dibuat.

\section{Refleksi (Refleting)}

Setiap siklus saling berkaitan dan berhubungan, karena hasil refleksi akan digunakan sebagai acuan untuk perbaikan pada siklus berikutnya. Diharapkan setiap siklus ada peningkatan yang signifikan mengenai peningkatan hasil belajar Bahasa Indonesia. Penelitian Tindakan Kelas ini berfokus pada perubahan dan peningkatan dalam pelaksanaan pembelajaran di setiap siklus. Hasil refleksi dari siklus ke siklus dapat memberikan konstribusi terhadap peningkatan pencapaian hasil pembelajaran siswa.

Metode analisis data yang digunakan pada penelitian ini adalah metode analisis statistic deskriptif kuantitatif. Adapun langkah-langkah yang dilakukan dalam analisis data adalah: 1) Mengumpulkan data, 2) Menyeleksi data, 3) Mengklasifikasi data, dan 4) Menghitung prosentase.

Indikator kinerja dibutuhkan dalam penelitian ini adalah agar pelaksanaan penelitian dapat berjalan sesuai rencana dan jadwal serta mendapatkan hasil yang positif dan sesuai dengan apa yang dikehendaki yaitu peningkatan hasil belajar siswa diharapkan dalam penelitian ini terjadi peningkatan yang baik diperoleh dari setiap siklus. Dengan hasil yang baik diperoleh dalam penelitian ini maka akan berdampak pada peningkatan kemampuan siswa dalam memahami konsep-konsep materi pelajaran Bahasa Indonesia secara lebih baik (Arikunto et al., 1990).

\section{Hasil Dan Pembahasan}

Hasil yang telah dicapai pada siklus I adalah meningkatnya hasil belajar siswa kelas XII. Akuntansi pada semester ganjil SMK Negeri 2 Rangkasbitung dan hal ini telah menunjukkan suatu bukti bahwa aktivitas dan pemahaman siswa terhadap materi pelajaran bahasa Indonesia tentang teks cerita Novel yang dilaksanakan dengan menerapkan model pembelajaran Discovery Learning.

Dari paparan hasil siklus I rata-rata nilai telah terjadi peningkatan dari pra siklus. Hasil capaian pada siklus I dengan nilai rata-rata kelas adalah 82 sedangkan ketuntasan belajar 
mencapai $88 \%$. Peningkatan hasil pembelajaran ini dicapai karena Peneliti menerapkan model pembelajaran Discovery Learning dimana siswa diberi bimbingan secara kontinju sampai mencapai kemahiran dalam memahami, mengidentifikasi serta menganalisis kebahasaan teks prosedur yang dipelajarinya.

Pencapai hasil pada siklus II berdasarkan penerapan model pembelajaran Discovery Learning, lebih diefektifkan pada siklus II. Bimbingan yang efektif mampu menstimulus siswa secara signifikan, sehingga mampu meningkatkan hasil belajar siswa dalam memaknai struktur teks cerita Novel dan hasil belajar mata pelajaran bahasa Indonesia meningkat. Adapun jumlah nilai rata-rata pada siklus II ini adalah 85,4 dan ketuntasan belajar mencapai $100 \%$. Peningkatan hasil yang dicapai siswa pada siklus II karena dilakukan refleksi secara maksimal melalui penerapan model pembelajaran Discovery Learning dalam pembelajaran. Siswa merasa terbina kemampuannya dalam memaknai konsep teks cerita novel dengan baik.

Keseluruhan hasil yang telah dicapai dalam penelitian tindakan kelas ini dapat disajikan dalam tabel dibawah ini.

Tabel 01. Rekapitulasi Hasil Penelitian Tindakan Kelas pada pretest /Prasiklus, siklus I, dan siklus II siswa kelas XII Akuntansi SMK Negeri 2 Rangkasbitung Tahun pelajaran 2018/2019

\begin{tabular}{|c|c|c|c|c|c|}
\hline \multirow[t]{2}{*}{ No. } & \multirow[t]{2}{*}{ Kreteria } & \multicolumn{3}{|c|}{ Jenis Tindakan } & \multirow[t]{2}{*}{ Ket. } \\
\hline & & Pre test/Prasiklus & S.I & S.II & \\
\hline 1. & Jumlah Nilai & 2477 & 2624 & 2733 & Meningkat \\
\hline 2. & Rata-rata Nilai & 77,4 & 82 & 85,4 & Meningkat \\
\hline 3. & $\begin{array}{l}\text { Ketuntasan } \\
\text { Belajar }\end{array}$ & $37 \%$ & $88 \%$ & $100 \%$ & Meningkat \\
\hline 4 & $\begin{array}{l}\text { Siswa Yang } \\
\text { Belum Tuntas }\end{array}$ & $63 \%$ & $12 \%$ & 0 & \\
\hline
\end{tabular}

Tabel di atas dapat disajikan ke dalam grafik berikut.

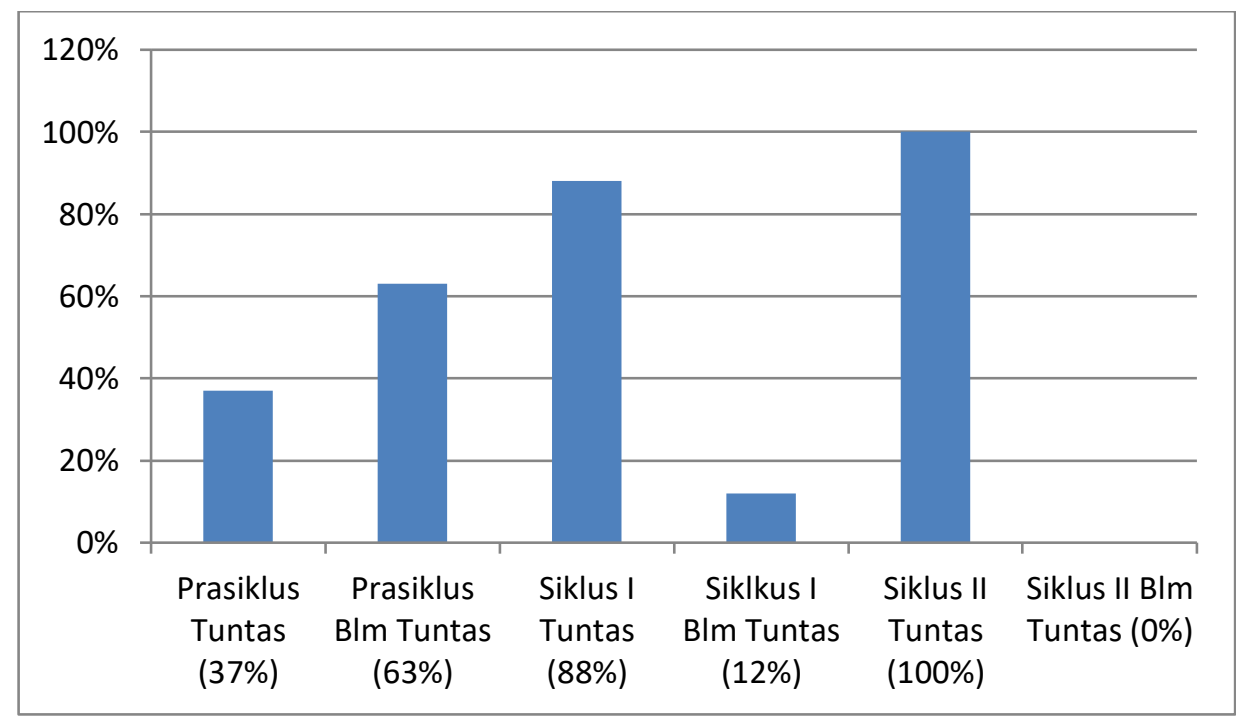

Grafik 1. Hasil Penelitian Tindakan Kelas

Hasil penelitian ini sejalan dengan hasil penelitian yang dilakukan oleh Hadiono dan Nuor (2016) dengan judul Penerapan Model Pembelajaran Discovery Learning Untuk Meningkatkan Motivasi dan Hasil Belajar Siswa Kelas VIII-D SMPN 2 Kamal Materi Cahaya. Berdasarkan hasil analisis data, terdapat peningkatan hasil belajar sebesar $9,79 \%$ ditinjau dari hasil pretest dan posttest yang diberikan untuk siklus I dan 11,79\%untuk siklus II. Sedangkan persentase motivasi siswa dalam mengikuti pembelajaran IPA sebesar $70 \%$ siklus I dan $77 \%$ siklus kedua yang mengindikasikan bahwa model Discovery Learning ini cocok atau layak 
untuk digunakan terhadap subyek penelitian tersebut. Dengan hasil yang dicapai tersebut dapat disimpulkan bahwa dalam pembelajaran terjadi peningkatan hasil belajar dan motivasi belajar pada siswa kelas VIII D SMPN 2 Kamal dengan menggunakan penerapan Discovery Learning.

\section{Simpulan}

Secara keseluruhan hasil Penelitian Tindakan Kelas yang dilaksanakan di kelas XII Akuntansi SMK Negeri 2 rangkasbitung telah di paparkan pada bab IV. Pada Bab V disajikan tentang kesimpulan dari seluruh kegiatan Penelitian Tindakan Kelas terhadap pembelajaran Bahasa Indonesia dengan materi teks cerita Novel bagi siswa kelas XII. Akuntansi Semester Ganjil SMK Negeri 2 Rangkasbitung Tahun pelajaran 2018/2019. Penelitian Tindakan kelas yang dilaksanakan di kelas XII. Akuntansi pada semester ganjil SMK Negeri 2 Rangkasbitung tahun pelajaran 2018/2019 terhadap mata pelajaran bahasa Indonesia dengan materi teks cerita novel telah menghasilkan suatu kesimpulan. Hasil yang diperoleh bahwa dengan penerapan model pembelajaran Discovery Learning dalam pelajaran Bahasa Indonesia, mampu meningkatkan hasil belajar siswa dan memotivasi siswa dalam meningkatkan semangat belajarnya serta membuat siswa tidak jenuh dalam mengikuti pembelajaran Bahasa Indonesia.

\section{Daftar Pustaka}

Ahmadi, Mukhsin. 1990. Strategi Belajar Mengajar Keterampilan Berbahasa dan Apresiasi Sastra. Malang : YA3 Malang.

Aminudin. 1987. Pengantar Apresiasi Karya Sastra. Malang : YA3 Malang.

Arikunto, Suharsimi, Suharjono, dan Supardi. 2008. Penelitian Tindakan Kelas. Jakarta: Bumi Aksara.

Departemen Pendidikan Nasional. 2005. Kamus Besar Bahasa Indonesia. Jakarta: Balai Pustaka.

Hadiono dan Nuor, Ainiy Hidayati. 2016. Penerapan Model Pembelajaran Discovery Learning Untuk Meningkatkan Motivasi dan Hasil Belajar Siswa Kelas VIII-D SMPN 2 Kamal Materi Cahaya. Jurnal Pena Sains Volume 3 Nomor 2.

Halim, Amran, Jazir Burhan, dan Haroen Al Rasjid. 1982. Ujian Bahasa. Jakarta : PT. Wira Nurbakti.

Hidayat, Kosadi, Jazir Burhan, dan Undang Misdan. 1990. Strategi Belajar Mengajar Bahasa Indonesia. Bandung: Bina Cipta.

Husnan, Ema, DKK. 1987. Apresiasi Sastra Indonesia. Bandung: Angkasa.

Maria Rosa Anggraini, SS. 2010. 1001 ulasan Bahasa Indonesia SMP kelas VIII. Scientific Press.

Samuel S. Lusi, Ricky Arnold Nggili. 2013. Panduan Praktis dengan Pendekatan IImiah untuk Melakukan Transformasi Pembelajaran. Yogyakarta: CV Andi Offset.

Siregar, Sori. 2001. Titik Temu: Kumpulan Cerita Pendek. Jakarta: Balai Pustakan.

Tarigan, Henry Guntur. 1987. Membaca Sebagai Suatu Keterampilan Berbahasa. Bandung: Angkasa. 